\title{
Building Productivity Models for Small Enhancements
}

\author{
Jean-Marc Desharnais ${ }^{1,2}$, Gülşah Yıldızoğlu ${ }^{1}$, Alain April ${ }^{2}$, Alain Abran ${ }^{2}$ \\ ${ }^{1}$ Boğaziçi University, Istanbul, Turkey; ${ }^{2}$ Department of Software Engineering and IT, École de Technologie Supérieure, Montréal, \\ Canada. \\ Email: desharnaisjm@gmail.com
}

Received January $9^{\text {th }}, 2013$; revised February $10^{\text {th }}, 2013$; accepted February $18^{\text {th }}, 2013$

\begin{abstract}
Software is in constant evolution and many approaches have been suggested to study software maintenance productivity. This research reports on a process to design and implement a productivity model of legacy software based on the measurement of small functional enhancements using the COSMIC ISO 19761 international standard. Two motivations influence this research: 1) understanding the productivity of the software maintenance process to help manage the cost of maintenance; 2) understanding the cost drivers that affect the software maintenance productivity. This research reports on an empirical study of a productivity measurement program implemented in a large banking legacy system.
\end{abstract}

Keywords: Small Enhancements; Productivity; Productivity Models; Maintenance; Cost of Maintenance

\section{Introduction}

\subsection{Definition of Maintenance}

The software lifecycle can be divided into two distinct parts, as presented in ISO 12207 [1]: the initial development of the software and its use and ongoing maintenance.

The international standard ISO 14764 [2] on software maintenance defines four categories to classify the nature of individual maintenance work requests: adaptive, corrective, preventive, and perfective (see Table 1).

ISO 14764 classifies adaptive and perfective maintenance as enhancements, and the corrective and preventive maintenance as corrections [2]. This research is focused mainly on adaptive and corrective work requests where most of the changes to functionality occur.

Table 1. ISO 14764 Software maintenance categories.

\begin{tabular}{cc}
\hline Category & Description \\
\hline Adaptive & $\begin{array}{c}\text { Modifications to adapt a software product to } \\
\text { change in data requirements and } \\
\text { processing environments }\end{array}$ \\
Corrective & $\begin{array}{c}\text { Reactive modification of a software product } \\
\text { performed after delivery to correct the faults } \\
\text { discovered. These modifications often repair code } \\
\text { to satisfy functional requirements }\end{array}$ \\
Preventive & $\begin{array}{c}\text { Modification of a software product after delivery } \\
\text { to detect and correct latent faults before they } \\
\text { become operational faults }\end{array}$ \\
Perfective & $\begin{array}{c}\text { Modification of a software product after delivery } \\
\text { implementing new or changed user requirements } \\
\text { which concern functional enhancements } \\
\text { to the software }\end{array}$ \\
\hline
\end{tabular}

In large organizations, most of the IT personnel are assigned to software maintenance-see Table 2 [3]. However, software maintenance is still a rather neglected activity by both IT managers and academic research according to a number of authors (Torchiano, Ricca, and De Lucia [4], Koskinen [5], Kuhlmann [6]). Already in 1996 Basili et al. were reporting that there were not enough empirical studies and available research data for software maintenance [4] while Koskinen [5] was reporting that "Software maintenance and evolution is a considerably understudied area while taking into account its cost effect". Many of the empirical studies on software maintenance management date back to the pre-2000, such as Abran [7], Lehman [8], Genuchten [9], Arfa [10], Desharnais [11] and others.

Table 2 published in 2006 shows that between 2000 and 2005 there was an increase of nearly $4 \%$ of the maintenance personnel in USA [12]. The projection for the following years is showing that the number of personnel in maintenance would increase considerably over

Table 2. USA software personnel in software development and maintenance $-2006[12]$.

\begin{tabular}{ccccc}
\hline Year & $\begin{array}{c}\text { Development } \\
\text { personnel }\end{array}$ & $\begin{array}{c}\text { Maintenance } \\
\text { personnel }\end{array}$ & $\begin{array}{c}\text { Total } \\
\text { personnel }\end{array}$ & $\begin{array}{c}\text { Maintenance } \\
\text { percent }\end{array}$ \\
\hline 2000 & 750,000 & $2,000,000$ & $2,750,000$ & $72.73 \%$ \\
2005 & 775,000 & $2,500,000$ & $3,275,000$ & $76.34 \%$ \\
2010 & 800,000 & $3,000,000$ & $3,800,000$ & $78.95 \%$ \\
2015 & $1,000,000$ & $3,500,000$ & $4,500,000$ & $77.78 \%$ \\
2020 & $1,100,000$ & $3,750,000$ & $4,850,000$ & $77.32 \%$ \\
2025 & $1,250,000$ & $4,250,000$ & $5,500,000$ & $77.27 \%$ \\
\hline
\end{tabular}


the next 20 years.

\subsection{Research Motivation}

This paper presents an empirical study of 88 small functional enhancements to a software system from the core banking ERP legacy system of a large retail bank to figure out the productivity of a maintenance process. More specifically, the motivations of this paper are: 1) to understand the productivity of the software maintenance process to help manage the cost of maintenance; and 2) to understand the cost drivers that affect the software maintenance productivity.

Benestad et al. [13] presents an overview of recent approaches by researchers for software maintenance improvements: maturity models to help with software maintenance process improvement initiatives $[14,15]$, estimation of maintenance costs [16], insights into the preconditions for measuring software maintenance productivity $[14,17]$ and direct analysis of productivity models $[4,10]$. As suggested by those authors, the main hypothesis in the design of productivity models specific to software maintenance is that such models should distinguish between the product, resources and processes data. More specifically, Benestad et al. reports that "Investigations into cost drivers during software maintenance and evolution have investigated the effects of project properties such as maintainer skills, team size, development practices, execution environment, and documentation" [13].

In this organization, IT management was interested in understanding and updating their existing productivity models for the following reasons:

- Productivity data on software maintenance was no longer up to date (older than 10 years);

- Leveraging the new 2nd generation of functional size measurement method, namely the COSMIC ISO
19761 measurement method [18] independently of the programming language technology and with a finer measurement granularity [19];

- A productivity model built from an up to date data sample more representative of their current software portfolio;

- A capability to tackle both management and customers questions about software maintenance productivity.

The rest of this paper is structured as follows. Section 2 presents the data collection and the process to build a productivity model for software maintenance. Section 3 presents the data set of the case study. Section 4 presents the data analysis and, Section 5 presents the conclusion and future work.

\section{The Data Collection Process}

For this empirical study, the productivity model is built in two phases:

1) A rigorous data collection process to collect reliable data-steps 1 to 5 in Figure 1.

2) Implementing a rigorous process to design a productivity model — steps 6 and 7 in Figure 1.

The following sub-sections explain the building process of the productivity model as sketched in Figure 1.

\subsection{Identification of Each Small Enhancement}

A change request (CR) is defined in ISO 14764 [2] as "proposed changes to a product that is being maintained". The data was collected through the system change request (CR) process implemented at the bank. The maintenance manager then looks at individual request, prioritizes it and, next, assigns it to a maintainer who will conduct the impact analysis and address it. A specific team handlesthe maintenance requests received for one specific system module.

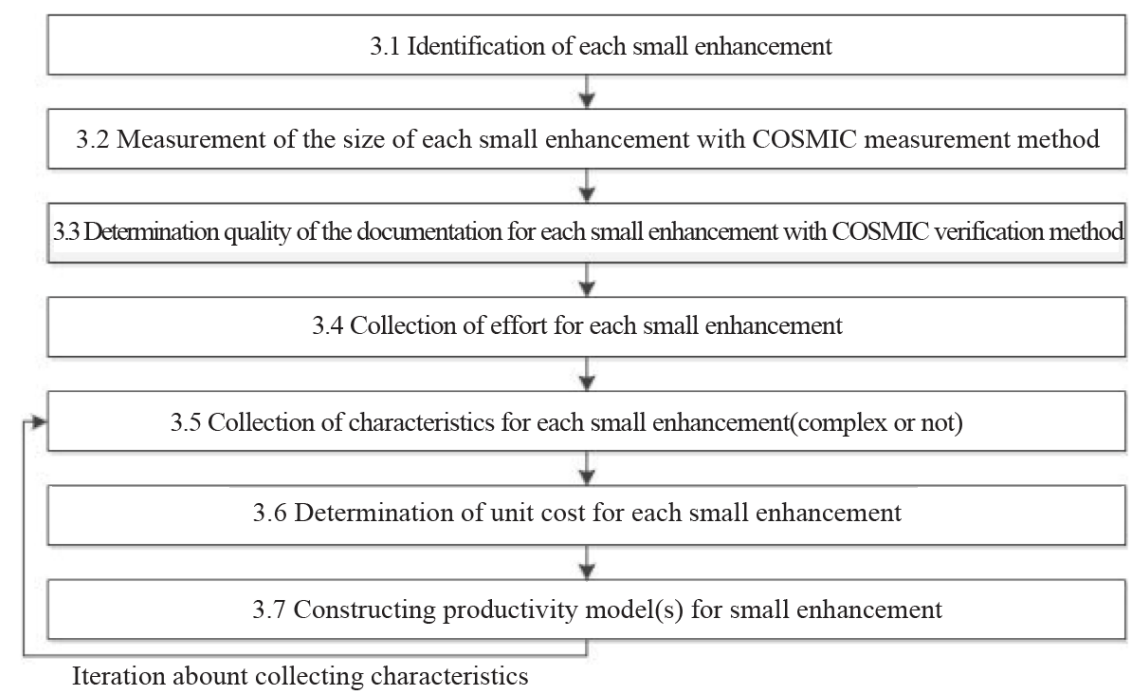

Figure 1. Steps to design the productivity model. 
Adaptive and corrective maintenance:

- The enhancements with the effort less than 3 weeks of effort ${ }^{1}$ were selected for analysis.

- All from the same core banking application, ensuring the same application domain (i.e., management information system - MIS), programmed on an IBM mainframe environment: e.g., COBOL, PL/1 or tools like Cool:Genusing DB2 or Oracle databases.

\subsection{Measurement of the Size of Each Small Enhancement}

Each 88 small enhancements, being a functional process, represent enough data points to fulfill good statistical conditions for the sixth criteria. These small enhancements (adaptive and corrective only) were designed, programmed and implemented on the same large core banking ERP application from April 2010 to December 2011. Each small enhancement had documented and well understood characteristics, in the change request system of the bank, such as: the programming language used, types (i.e. batch vs. online), and tools used-see Appendix A for more details.

These 88 small functional enhancements were measured by the same "maintainer" and next verified by an independent COSMIC certified expert. In this step, the COSMIC [18] measurement method was used to determine the size of each small enhancement. To measure the size of a small enhancement, all of its functional processes were identified, and then measured in terms of COSMIC function points (CFP). The maintainer who applied the measurement method was the one who analyzed, programmed and implemented each small enhancement. Afterwards, an independent functional measurement expert verified the number of CFP obtained for each functional process based on the documentation of each small enhancement (see examples in Appendix A). Each small enhancement had a functional size of less than twenty CFP (COSMIC Function Points).

\subsection{Determination of the Quality of the Information Provided for Each Small Enhancement}

The documentation was produced and controlled by the same maintainer who had implemented the small enhancements. The quality of the documentation of each small enhancement was assessed based on the COSMIC verification process requirements [19]. This activity helps verify the quality of the functional size results. The determination of the quality of the documentation can be assessed based on: 1) the presence or absence of a data model; 2) the availability of the description of the data

${ }^{1}$ It was decided by the organization analyzed that if an enhancement works take more than three weeks it fall in another category. movements; and 3) the identification of each functional process in the software. Because the maintainer who had done the maintenance was present during this exercise, it was possible to complete the documentation, when needed. The resulting quality of the documentation related to small enhancements used in this case study is considered as high (i.e., of very good quality) based on the quality rating (Appendix A).

\subsection{Collection of Effort for Each Small Enhancement}

The maintainers recorded the effort information on a daily basis.

- Duration between half a day and 3 weeks. Effort and duration measures were available and reliable.

- A small team of 1 or 2 maintainers executed every small enhancement.

\subsection{Collection of Characteristics of Each Small Enhancement}

The data available to analyze characteristics are: 1) functional size [18]; 2) maintenance categories (adaptive and corrective maintenance types are handled); 3) development tool (Cool:Gen versus PL/1); 4) batch versus online programs. Cost drivers are used in this empirical study to analyze their influence on the effort.

\subsection{Determination of Unit Cost for Each Small Enhancement}

After the maintenance requests are ordered according to efforts, the number of functional points per hour is used to calculate the productivity ratio while the unit cost is determined by dividing effort (input) required to develop small enhancements to functional size (output) of each small enhancement.

$\frac{\text { Effort }}{\text { Functional Size }}$

\subsection{Constructing Productivity Model(s) for Small Enhancements}

A productivity model is typically built with data from CRs completed, when all information on a CR is available and that there is no more uncertainty: all of the software functions have been delivered and all of the number of hours for the project have been completed and measured.

\section{Presentation of the Dataset}

This section presents a descriptive analysis of the dataset. Table 3 shows the minimum, maximum, average and standard deviation of the functional size (in number of CFP) and effort (in person-hours) of this data set. In 
Table 3. Distribution of CFP and hours.

\begin{tabular}{ccccc}
\hline & Min. & Max. & Avg. & Std. Dev. \\
\hline CFP & 3 & 13 & 5.0 & 2.1 \\
Effort & 1 & 40 & 9.9 & 8.4 \\
\hline
\end{tabular}

Table 3, the functional size of the for small enhancements varies from 3 to $13 \mathrm{CFP}$, while the effort in hours varies from 1 to 40 hours. The average functional size of a small enhancement is 5 CFP with a standard deviation of 2.1 CFP. The average number of hours is 9.9 with a standard deviation of 8.4 hours.

Table 4 presents the others variables. Those variables are related to the programming (PL/1 or Cool:Gen), the access type (Batch or Online) and the type of maintenance (adaptive or corrective). Since these variables are descriptive, they must be transformed into dummy variables, where eachcandidate value isbinary (either 0 or 1 : presence or absence) for each of those category of variable .

In Table 4, the number of small enhancements program in PL/1 is 39 , and in Cool:Gen 49 . The types of access for small enhancements are respectively 39 and 49 , and the type of enhancement are 51 for adaptive and 26 for corrective. There is no information for 11 small enhancements or they are mixed. Also, when looking at the data (Appendix A) it shows that the PL/1 is always associated with Batch and Cool:Gen with Online. For this reason it is not possible to analyze those variables independently.

\section{Analysis of the Data}

SPSS was used to analyze the data with regression statistics. The acceptance of regression results hinges on diagnostic checking for the acceptance of "classical assumptions" [20]. In software engineering, the classical assumption is that the size should explain $70 \%$ of the effort $80 \%$ of the time. For this analysis, if the regression analysis is showing a result greater than 0.70 , this will confirm the "classical assumption" [20].

\subsection{Regression Analysis Procedure}

To proceed for a regression analysis it is necessary to follow the procedure commended in [20].

A) Steps before starting the regression:

1) Define the methodology to build the regression model for productivity (Section 2).

2) Decide which variable will be used in the model.

3) Choose the statistical tool and enter the data for statistical analysis.

4) Use descriptive analysis to find outliers. From the descriptive statistics no outlier is present for the quantitative variables (functional size and effort) in the data set
Table 4. Others variables.

\begin{tabular}{ccc}
\hline Variable & Category & Number of enhancements \\
\hline $\begin{array}{c}\text { Programming } \\
\text { language }\end{array}$ & PL/1 & 39 \\
& Cool:Gen & 49 \\
Type of programs & Batch & 49 \\
& Online & 39 \\
Type of maintenance & Adaptive & 51 \\
& Corrective & 26 \\
\hline
\end{tabular}

used.

B) Steps for the regression analysis:

1) Choose which variables will be analyzed.

2) Run a regression analysis.

3) Present the results.

4) Interpret the results.

5) Accept or reject the results (in the productivity model).

6) Start again with new choices of variables.

\subsection{Linear Regression Models}

It is not possible to present all the results. Only some of them will be presented following the proposed steps:

1) Choose which variables will be analyzed.

In this regression analysis, the functional size of small enhancements is selected as the dependent variable and effort as the independent variable in the model. This analysis aims to find the relation between functional size and effort: Effort = function (functional size in CFP)

2) Run a regression analysis.

SPSS was chosen to run a linear regression analysis with the ANOVA (Table 4).

Table 5 shows the regression analysis and the ANOVA, and Figure 2 the corresponding regression plot. In Figure 2 the regression plot is based on 88 small enhancements points at the intersection of the size (CFP) and the effort. There is no obvious outlier that can be seen.

3) Interpret the results.

The coefficient of determination (i.e. $\mathrm{R}^{2}$ ) result is 0.75 . This study considers that a $R^{2}$ of 0.70 is acceptable in software engineering. For the Anova in Table 5, the last column Sig. shows the goodness of fit of the model. If this number is smaller than 0.01 then the model is significant at $99 \%$, if it is smaller than 0.05 then the model is significant at $95 \%$, and if it less than 0.1 the model is significant at $90 \%$ [20]. Significance implies the acceptance of the model: the lower this number, the better it fits. For the Anova in Table 5, the Sig. value of 0.000 confirms the significance of the model at more than $99 \%$.

The result is acceptable from the goodness of the fit. The number of CFP explains more than $75 \%$ of the 
Table 5. Regression analysis and Anova.

\begin{tabular}{|c|c|c|c|c|c|c|}
\hline \multicolumn{7}{|c|}{ Variables Entered/Removed ${ }^{a}$} \\
\hline Model & \multicolumn{3}{|c|}{$\begin{array}{l}\text { Variables } \\
\text { Entered }\end{array}$} & $\begin{array}{l}\text { Variables } \\
\text { Removed }\end{array}$ & \multicolumn{2}{|c|}{ Method } \\
\hline 1 & \multicolumn{3}{|c|}{$\mathrm{CFP}^{\mathrm{b}}$} & & \multicolumn{2}{|c|}{ Enter } \\
\hline \multicolumn{7}{|c|}{ aependent variable: Effort; ${ }^{\mathrm{b}} \mathrm{All}$ requested variables entered. } \\
\hline \multicolumn{7}{|c|}{ Model Summary } \\
\hline Model & $\mathbf{R}$ & \multicolumn{2}{|c|}{ R Square } & $\begin{array}{c}\text { Adjusted R } \\
\text { Square }\end{array}$ & \multicolumn{2}{|c|}{$\begin{array}{c}\text { Std. Error of the } \\
\text { Estimate }\end{array}$} \\
\hline 1 & $0.870^{\mathrm{a}}$ & \multicolumn{2}{|c|}{0.757} & 0.754 & \multicolumn{2}{|c|}{4.155} \\
\hline \multicolumn{7}{|c|}{ apredictors: (Constant), CFP. } \\
\hline \multicolumn{7}{|c|}{ ANOVA $^{\mathrm{a}}$} \\
\hline Model & & $\begin{array}{l}\text { of } \\
\text { ires }\end{array}$ & df & $\begin{array}{c}\text { Mean } \\
\text { Square }\end{array}$ & $\mathbf{F}$ & Sig. \\
\hline $\begin{array}{c}\text { Regression } 1 \\
\text { Residual } \\
\text { Total }\end{array}$ & $\begin{array}{l}4,6 \\
1,48 \\
6,10\end{array}$ & $\begin{array}{l}496 \\
, 948 \\
443\end{array}$ & $\begin{array}{c}1 \\
86 \\
87\end{array}$ & $\begin{array}{c}4,617,496 \\
17,26\end{array}$ & 267,420 & $0,000^{\wedge} \mathrm{b}$ \\
\hline
\end{tabular}

${ }^{\mathrm{a}}$ Dependent variable: Effort, ${ }^{\mathrm{b}}$ Predictors: (Constant), CFP.

variance in the effort.

4) Start again from new choices of variables.

\subsection{Linear Regression Models}

In the previous models, only two variables were used. The next question is: is it possible to improve the regression value using some other variables or multiple variables?

Table 5 presents the multi-regressions results for the three (3) independent cost drivers analyzed, together with the independent variable CFP, and the dependent variable effort.

Table 5 shows that the $\mathrm{R}^{2}$ is constantly over 0.75 , which means that independents variables (adaptive/corrective, online/batch) used for regression analysis explain more than $75 \%$ of the variance in the effort variable. The ANOVA still have a Sig. of 0.000 for all three multi-regressions and the plot is not very useful because of the binary nature of each variable. However, none of these additional independent variables adds much to the explanation of the relationship with functional size and effort, which already had an $\mathrm{R}^{2}$ of 0.75 , thereby, the contribution of these additional variables, concurrently, is minimal.

\section{Average Unit Cost}

This research also presents the average unit costs using a number of cost drivers.

Table 6 shows that the average unit cost for all the data is 1.81 hours per CFP with a difference between the lowest and highest average of 0.9 hours for 88 small enhancements.

Table 7 shows that that the lowest unit cost is for
Table 6. Multi-regression models.

\begin{tabular}{cccc}
\hline $\begin{array}{c}\text { Independent } \\
\text { Variables }\end{array}$ & $\begin{array}{c}\text { Size \& Adaptive/ } \\
\text { Corrective }\end{array}$ & $\begin{array}{c}\text { Size \& } \\
\text { Online/Batch }\end{array}$ & $\begin{array}{c}\text { Size \& } \\
\text { PL1/Cool:Gen }\end{array}$ \\
\hline $\mathrm{R}^{2}$ & 0.773 & 0.761 & 0.759 \\
\hline
\end{tabular}

Table 7. Unit cost per variable.

\begin{tabular}{cc}
\hline Variables & Average hours/CFP \\
\hline All data & 1.8 \\
Batch & 1.6 \\
Online & 2.0 \\
Adaptive & 1.4 \\
Corrective & 2.5 \\
\hline
\end{tabular}

Adaptive maintenance (1.4 hrs/CFP), while corrective maintenance costs almost twice as much ( $2.5 \mathrm{hrs} / \mathrm{CFP})$. For Batch and Online the average is 1.6 and 2.0 hours/ CFP respectively.

\section{Conclusions and Future Works}

The following five criteria were followed in this empirical study:

1) Use of an internationally recognized functional size measurement method to measure every small functional enhancement, that is: the COSMIC ISO 19761 measurement method [17] was used to measure the functional size of each small enhancement (functional processes were measured and verified).

2) Assessment of the quality of the documentation used for the sizing of each functional enhancement.

3) A controlled environment for the maintenance personnel that worked on the enhancements.

4) Implementation of a reliable effort data collection mechanism for each small enhancement.

5) Documentation of the individual characteristics of each small enhancements included in this empirical study. Enough data points (individual enhancements) are collected to build a valid productivity model.

Using those criteria, it was possible to produce a productivity model with this sample using all independent variables $\left(R^{2}\right.$ of more than 0.75$)$ of a specific large retail bank.

The productivity is $20 \%$ better using Online, instead of Batch mode (Table 6). Unit cost is also better (almost $60 \%$ decrease) for adaptive maintenance compare to corrective maintenance.

There were a number of homogeneous empirical conditions to construct this productivity model (Table 4 and Figure 2): functional enhancements to the same major software banking application within a single organization, each distinct functional enhancement designed, 


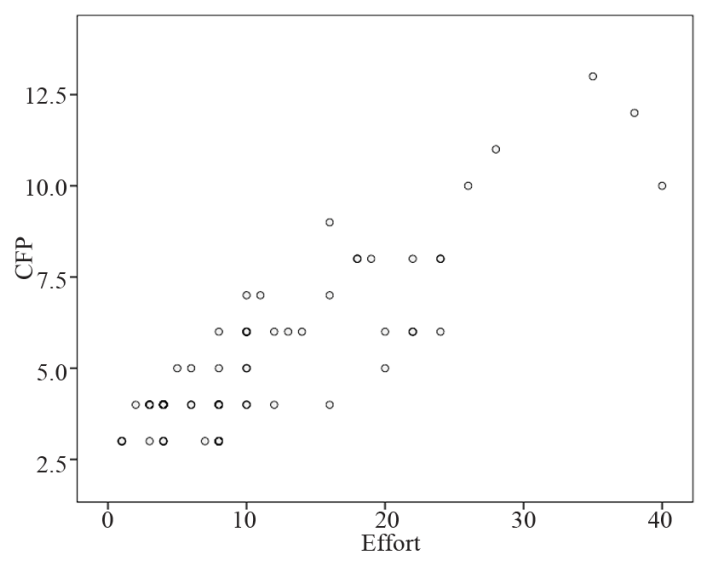

Figure 2. Regression plot with size $\&$ effort.

programmed and implemented by the same person, documented by the maintainer, measured within a controlled environment and verified by a measurement expert.

While this type of situation is common in practice, availability of such data for empirical analysis is scarce. On the other hand, such homogeneity limits the generalization of the results to other contexts, such as different software applications. Availability of additional data sets is therefore necessary for further research work.

\section{REFERENCES}

[1] ISO/IEC 12207, Systems and Software EngineeringSoftware Life Cycle Processes, International Organization for Standardization, Geneva, 2008.

[2] ISO/IEC 14764, Software Engineering-Software Life Cycle Processes-Maintenance, International Organization for Standardization, Geneva, 2006.

[3] M. Maya, A. Abran and P. Bourque, "Measuring the Size of Small Functional to Enhancements Software," The 6th International Workshop on Software Measurement, Regensburg, 19-20 September 1996.

[4] J. Koskinen, "Software Maintenance Costs," University of Jykäskylä, Finland, 2010.

[5] M. Torchiano, F. Ricca and A. De Lucia, "Empirical Studies in Software Maintenance and Evolution," IEEE International Conference on Software Maintenance, Paris, 2-5 October 2007, pp. 491-494.

[6] U. Kuhlmann, "Maintenance Activities in Software Process Models: Theory and Case Study Practice," Master Thesis, University of Koblenz Landau, Koblenz, 2003, pp. $1-135$.

[7] A. Abran and H. Nguyenkim, "Analysis of Maintenance Work Categories through Measurement," IEEE International Conference on Software Maintenance, Sorrento, 15-17 October 1991, pp. 104-113.
[8] M. M. Lehman, "System Maintenance and Evolution in an Era of Reuse, COTS, and Component-Based Systems," International Conference on Software Maintenance (ICSM), Oxford, 30 August 1999.

[9] M. Van Genuchten, G. Brethouwer, T. Van den Boomen and F. J. Heemstra, "An Empirical Study of Software Maintenance," Information and Software Technology, Vol. 34, No. 8, 1992, pp. 507-512. doi:10.1016/0950-5849(92)90144-E

[10] L. B. Arfa, A. Mili and L. Sekhri, "An Empirical Study of Software Maintenance," Proceedings of Conference on Software Maintenance, Sorrento, 15-17 October 1991, pp. 52-58.

[11] J. M. Desharnais, F. Pare, M. Maya and D. St-Pierre, "Implementing a Measurement Program in Software Maintenance: An Experience Report Based on Basili's Approach," IFPUG Spring Conference, Cincinnati, 1997.

[12] C. Jones, "The Economics of Software Maintenance in the Tweenty First Century," 2006.

[13] H. C. Benestad, B. Anda and E. Arisholm, "Understanding Software Maintenance and Evolution by Analyzing Individual Changes: A Literature Review," Journal of Software Maintenance and Evolution: Research and Practice, Vol. 21, No. 6, 2009, pp. 349-378. doi: $10.1002 /$ smr.412

[14] A. April and A. Abran, "Software Maintenance Management: Evaluation and Continuous Improvement," Wiley-IEEE Computer Society Press, Honoken, 2008. doi:10.1002/9780470258033

[15] M. Kajko-Mattsson, "Corrective Maintenance Maturity Model $\left(\mathrm{CM}^{3}\right)$ : Maintainer's Education and Training," Proceedings of the 23rd International Conference on Software Engineering, Toronto, 12 May 2001, pp. 610-619.

[16] A. Abran, "Estimation Models for Software Maintenance Based on Functional Size," Journal of Software Technology, Vol. 9, No. 3, 2006, pp. 18-25.

[17] A. April, A. Abran and R. R. Dumke, "Software Maintenance Productivity Measurement: How to Assess the Readiness of Your Organization, Software Maintenance Productivity Measurement," IWSM/Metrikon, 2004.

[18] Measurement Manual v3.0.1 (The COSMIC Implementation Guide for ISO/IEC 19761: 2003), 2009, The Common Software Measurement International Consortium (COSMIC), 2012.

[19] The COSMIC Functional Size Measurement Method Version 3.0.1 Guideline for Assuring the Accuracy of Measurements Version 0.92, Common Software Measurement International Consortium, 2011.

[20] Regression Explained in Simpler Terms, A Vijay Gupta Publication, SPSS for Beginners, 2000. https://mywebspace.wisc.edu/rlbrown3/web/library/regres sion_explained.pdf 
Appendix A. List of the Small Enhancements with Measures

\begin{tabular}{|c|c|c|c|c|c|c|c|c|c|c|c|c|c|c|c|c|}
\hline No & Identification & $\mathbf{E}$ & $\mathbf{R}$ & $\mathbf{W}$ & $\mathbf{X}$ & CFP & Effort & Type & Ratio & Tool & Quality & Batch & Online & Write & Exit & Module \\
\hline 1 & $\begin{array}{l}\text { Changing General Ledger } \\
\text { Numbers of Retail Credit }\end{array}$ & 1 & 1 & 1 & 1 & 4 & 4 & M & 1.00 & $\mathrm{PL} / \mathrm{I}$ & A & Y & $\mathrm{N}$ & 0 & 0 & 1 \\
\hline 2 & $\begin{array}{l}\text { Changing General Ledger } \\
\text { Numbers of Commercial Credits }\end{array}$ & 1 & 1 & 1 & 1 & 4 & 4 & M & 1.00 & $\mathrm{PL} / \mathrm{I}$ & A & Y & $\mathrm{N}$ & 0 & 0 & 1 \\
\hline 3 & $\begin{array}{l}\text { Changing General Ledger } \\
\text { Numbers of Overdue Credits }\end{array}$ & 1 & 1 & 1 & 1 & 4 & 4 & M & 1.00 & $\mathrm{PL} / \mathrm{I}$ & A & Y & $\mathrm{N}$ & 0 & 0 & 1 \\
\hline 4 & $\begin{array}{l}\text { Calculation of Effective } \\
\text { Interest Rate of Retail Credits }\end{array}$ & 1 & 2 & 2 & 1 & 6 & 22 & $\mathrm{~N}$ & 3.67 & $\mathrm{PL} / \mathrm{I}$ & A & $\mathrm{Y}$ & $\mathrm{N}$ & 1 & 0 & 1 \\
\hline 5 & $\begin{array}{c}\text { Calculating Adjustment Amount of } \\
\text { Retail Credits }\end{array}$ & 1 & 2 & 2 & 1 & 6 & 20 & $\mathrm{~N}$ & 3.33 & $\mathrm{PL} / \mathrm{I}$ & A & Y & $\mathrm{N}$ & 1 & 0 & 1 \\
\hline 6 & Daily Adjustment Accounting & 1 & 5 & 1 & 1 & 8 & 18 & $\mathrm{~N}$ & 2.25 & $\mathrm{PL} / \mathrm{I}$ & A & $\mathrm{Y}$ & $\mathrm{N}$ & 0 & 0 & 0 \\
\hline 7 & $\begin{array}{l}\text { Changing Commission and } \\
\text { Income General Numbers of } \\
\text { Amortization Batch }\end{array}$ & 1 & 1 & 0 & 1 & 3 & 4 & M & 1.33 & $\mathrm{PL} / \mathrm{I}$ & A & $\mathrm{Y}$ & $\mathrm{N}$ & 0 & 0 & 0 \\
\hline 8 & $\begin{array}{l}\text { Transfer of Opening Commissions } \\
\text { related to Commercial Credits with } \\
\text { payment plan number to the } \\
\text { income system }\end{array}$ & 1 & 1 & 1 & 1 & 4 & 4 & M & 1.00 & $\begin{array}{l}\text { Cool: } \\
\text { Gen }\end{array}$ & A & $\mathrm{N}$ & $\mathrm{Y}$ & 0 & 0 & 0 \\
\hline 9 & $\begin{array}{l}\text { Transfer of Opening Commissions } \\
\text { related to Commercial Credits with } \\
\text { no payment plan number to the } \\
\text { income system (PL/I batch is used) }\end{array}$ & 1 & 1 & 0 & 1 & 3 & 3 & M & 1.00 & $\mathrm{PL} / \mathrm{I}$ & A & Y & $\mathrm{N}$ & 0 & 0 & 0 \\
\hline 10 & $\begin{array}{l}\text { Cancel amortization of opening } \\
\text { commissions related to commercial } \\
\text { credits with payment plan number } \\
\text { to the income system }\end{array}$ & 1 & 1 & 1 & 1 & 4 & 4 & $\mathrm{M}$ & 1.00 & $\begin{array}{l}\text { Cool: } \\
\text { Gen }\end{array}$ & A & $\mathrm{N}$ & $\mathrm{Y}$ & 0 & 0 & 0 \\
\hline 11 & $\begin{array}{l}\text { Transfer of Periodic Commissions } \\
\text { related to Commercial Credits with } \\
\text { payment plan number to the } \\
\text { income system }\end{array}$ & 1 & 1 & 0 & 1 & 3 & 4 & $\mathrm{M}$ & 1.33 & $\begin{array}{l}\text { Cool: } \\
\text { Gen }\end{array}$ & A & $\mathrm{N}$ & $\mathrm{Y}$ & 0 & 0 & 0 \\
\hline 12 & $\begin{array}{l}\text { Cancel amortization of periodic } \\
\text { commissions related to } \\
\text { commercial credits with payment } \\
\text { plan number to the income system }\end{array}$ & 1 & 1 & 1 & 1 & 4 & 4 & $\mathrm{M}$ & 1.00 & $\mathrm{PL} / \mathrm{I}$ & A & $\mathrm{Y}$ & $\mathrm{N}$ & 0 & 0 & 0 \\
\hline 13 & $\begin{array}{l}\text { Transfer of Opening Commissions } \\
\text { related to Retail Credits with } \\
\text { payment plan number to the } \\
\text { income system }\end{array}$ & 1 & 1 & 1 & 1 & 4 & 4 & $\mathrm{M}$ & 1.00 & $\begin{array}{l}\text { Cool: } \\
\text { Gen }\end{array}$ & A & $\mathrm{N}$ & $\mathrm{Y}$ & 0 & 0 & 0 \\
\hline 14 & $\begin{array}{l}\text { Cancel amortization of opening } \\
\text { commissions related to retail } \\
\text { credits with payment plan number } \\
\text { to the income system }\end{array}$ & 1 & 1 & 1 & 1 & 4 & 4 & $\mathrm{M}$ & 1.00 & $\begin{array}{l}\text { Cool: } \\
\text { Gen }\end{array}$ & A & $\mathrm{N}$ & $\mathrm{Y}$ & 0 & 0 & 0 \\
\hline 15 & $\begin{array}{l}\text { Transfer of Periodic Commissions } \\
\text { related to Retail Credits with } \\
\text { payment plan to the income system }\end{array}$ & 1 & 1 & 1 & 1 & 4 & 4 & $\mathrm{M}$ & 1.00 & $\mathrm{PL} / \mathrm{I}$ & A & $\mathrm{Y}$ & $\mathrm{N}$ & 0 & 0 & 0 \\
\hline 16 & $\begin{array}{l}\text { Cancel amortization of periodic } \\
\text { commissions related to commercial } \\
\text { retail income system }\end{array}$ & 1 & 1 & 1 & 1 & 4 & 4 & $\mathrm{M}$ & 1.00 & $\mathrm{PL} / \mathrm{I}$ & A & Y & $\mathrm{N}$ & 0 & 0 & 0 \\
\hline 17 & $\begin{array}{c}\text { Commercial Credits Commission } \\
\text { Rediscount Create }\end{array}$ & 1 & 1 & 1 & 1 & 4 & 2 & $\mathrm{M}$ & 0.50 & $\mathrm{PL} / \mathrm{I}$ & A & Y & $\mathrm{N}$ & 0 & 0 & 0 \\
\hline 18 & $\begin{array}{c}\text { Commercial Credits Commission } \\
\text { Rediscount Function }\end{array}$ & 2 & 2 & 2 & 1 & 7 & 10 & $\mathrm{~N}$ & 1.43 & $\mathrm{PL} / \mathrm{I}$ & A & Y & $\mathrm{N}$ & 1 & 0 & 0 \\
\hline 19 & $\begin{array}{l}\text { Calling IFRS general link to } \\
\text { calculate EIR, Adjustment and } \\
\text { Effective amount in Commercial } \\
\text { Credits Investment Rediscount }\end{array}$ & 1 & 2 & 2 & 1 & 6 & 10 & $\mathrm{~N}$ & 1.67 & $\begin{array}{l}\text { Cool: } \\
\text { Gen }\end{array}$ & A & $\mathrm{N}$ & $\mathrm{Y}$ & 1 & 0 & 0 \\
\hline 20 & $\begin{array}{c}\text { Calling IFRS general link to } \\
\text { calculate EIR, Adjustment and } \\
\text { Effective amount in Retail Credits } \\
\text { Investment Rediscount }\end{array}$ & 1 & 2 & 2 & 1 & 6 & 10 & $\mathrm{~N}$ & 1.67 & $\begin{array}{l}\text { Cool: } \\
\text { Gen }\end{array}$ & A & $\mathrm{N}$ & $\mathrm{Y}$ & 1 & 0 & 0 \\
\hline
\end{tabular}




\begin{tabular}{|c|c|c|c|c|c|c|c|c|c|c|c|c|c|c|c|c|}
\hline No & Identification & $\mathbf{E}$ & $\mathbf{R}$ & W & $\mathbf{X}$ & CFP & Effort & Type & Ratio & Tool & Quality & Batch & Online & Write & Exit & Module \\
\hline 21 & $\begin{array}{l}\text { Calling IFRS general link to } \\
\text { calculate EIR, Adjustment and } \\
\text { Effective amount in Retail } \\
\text { Credits Commission Rediscount }\end{array}$ & 1 & 2 & 2 & 1 & 6 & 8 & $\mathrm{~N}$ & 1.33 & Cool:Gen & A & $\mathrm{N}$ & Y & 1 & 0 & 0 \\
\hline 22 & $\begin{array}{l}\text { Cancel of calling amortization } \\
\text { create from periodic commission } \\
\text { collection of retail credits }\end{array}$ & 1 & 1 & 1 & 1 & 4 & 3 & M & 0.75 & PL/I & A & Y & $\mathrm{N}$ & 0 & 0 & 0 \\
\hline 23 & $\begin{array}{l}\text { Cancel of calling amortization } \\
\text { create from opening commission } \\
\text { collection of retail credits }\end{array}$ & 1 & 1 & 1 & 1 & 4 & 3 & M & 0.75 & Cool:Gen & A & $\mathrm{N}$ & Y & 0 & 0 & 0 \\
\hline 24 & $\begin{array}{l}\text { Cancel of calling amortization } \\
\text { create from periodic commission } \\
\text { collection of commercial credits }\end{array}$ & 1 & 1 & 1 & 1 & 4 & 3 & M & 0.75 & $\mathrm{PL} / \mathrm{I}$ & A & Y & $\mathrm{N}$ & 0 & 0 & 0 \\
\hline 25 & $\begin{array}{l}\text { Calling income system link from } \\
\text { periodic commission collection } \\
\text { of retail credits }\end{array}$ & 1 & 1 & 1 & 1 & 4 & 4 & M & 1.00 & PL/I & A & Y & $\mathrm{N}$ & 0 & 0 & 0 \\
\hline 26 & $\begin{array}{l}\text { Calling income system link from } \\
\text { opening commission collection } \\
\text { of retail credits }\end{array}$ & 1 & 1 & 1 & 1 & 4 & 4 & M & 1.00 & Cool:Gen & A & $\mathrm{N}$ & Y & 0 & 0 & 0 \\
\hline 27 & $\begin{array}{l}\text { Calling income system link from } \\
\text { periodic commission collection } \\
\text { of commercial credit }\end{array}$ & 1 & 1 & 1 & 1 & 4 & 4 & M & 1.00 & PL/I & A & Y & $\mathrm{N}$ & 0 & 0 & 0 \\
\hline 28 & $\begin{array}{l}\text { Cancel of calling amortization } \\
\text { create from accrual system } \\
\text { Calling commercial credits }\end{array}$ & 1 & 1 & 1 & 1 & 4 & 3 & M & 0.75 & PL/I & A & Y & $\mathrm{N}$ & 0 & 0 & 0 \\
\hline 29 & $\begin{array}{l}\text { Calling commercial credits } \\
\text { commission rediscount create } \\
\text { link from accrual system }\end{array}$ & 1 & 1 & 1 & 1 & 4 & 4 & M & 1.00 & PL/I & A & Y & $\mathrm{N}$ & 0 & 0 & 0 \\
\hline 30 & $\begin{array}{c}\text { Connection between income } \\
\text { system and amortization system } \\
\text { for opening commission records } \\
\text { of commercial credits with no } \\
\text { payment plan }\end{array}$ & 1 & 0 & 1 & 1 & 3 & 4 & M & 1.33 & Cool:Gen & A & $\mathrm{N}$ & Y & 0 & 0 & 1 \\
\hline 31 & $\begin{array}{l}\text { Extra Commission Collection } \\
\text { Facility for Commercial Credits }\end{array}$ & 1 & 6 & 5 & 1 & 13 & 35 & $\mathrm{~N}$ & 2.69 & Cool:Gen & A & $\mathrm{N}$ & Y & 1 & 0 & 1 \\
\hline 32 & $\begin{array}{l}\text { Extra Commission Collection } \\
\text { Facility for Retail Credits }\end{array}$ & 1 & 5 & 4 & 1 & 11 & 28 & $\mathrm{~N}$ & 2.55 & Cool:Gen & A & $\mathrm{N}$ & Y & 1 & 0 & 1 \\
\hline 33 & $\begin{array}{l}\text { Discarding new Transactions } \\
\text { from the First Level of } \\
\text { Accounting Unload }\end{array}$ & 1 & 1 & & 1 & 3 & 1 & M & 0.33 & $\mathrm{PL} / \mathrm{I}$ & A & Y & $\mathrm{N}$ & 0 & 0 & 0 \\
\hline 34 & $\begin{array}{l}\text { Adding new Transactions to the } \\
\text { Second Level of Accounting } \\
\text { Unload }\end{array}$ & 1 & 1 & & 1 & 3 & 1 & M & 0.33 & PL/I & A & Y & $\mathrm{N}$ & 0 & 0 & 0 \\
\hline 35 & $\begin{array}{l}\text { Loading accounting from excel } \\
\text { file to the system without using } \\
\text { general parametric accounting } \\
\text { link }\end{array}$ & 1 & 3 & 1 & 1 & 6 & 14 & $\mathrm{~N}$ & 2.33 & $\mathrm{PL} / \mathrm{I}$ & A & Y & $\mathrm{N}$ & 0 & 0 & 1 \\
\hline 36 & $\begin{array}{l}\text { Comparison of accounting } \\
\text { movement and account } \\
\text { movement to control trial } \\
\text { balance (in two ways: from } \\
\text { accounting to account movement } \\
\text { and from account movement to } \\
\text { accounting movement) }\end{array}$ & 1 & 2 & & 1 & 4 & 12 & M & 3,00 & PL/I & A & Y & $\mathrm{N}$ & 0 & 0 & 1 \\
\hline 37 & $\begin{array}{l}\text { Facility to insert general numbers } \\
\text { according to product }\end{array}$ & 1 & 3 & 1 & 1 & 6 & 10 & $\mathrm{~N}$ & 1.67 & Cool:Gen & A & $\mathrm{N}$ & $\mathrm{Y}$ & 0 & 0 & 0 \\
\hline 38 & $\begin{array}{l}\text { Facility to insert old product } \\
\text { codes and new products codes } \\
\text { into product change parameter } \\
\text { table }\end{array}$ & 1 & 2 & 1 & 1 & 5 & 6 & M & 1.20 & Cool:Gen & A & $\mathrm{N}$ & Y & 0 & 0 & 0 \\
\hline 39 & $\begin{array}{l}\text { NBR Opening Commission } \\
\text { Report of Retail Credits }\end{array}$ & 1 & 1 & 1 & 1 & 4 & 4 & M & 1.00 & $\mathrm{PL} / \mathrm{I}$ & A & Y & $\mathrm{N}$ & 0 & 0 & 0 \\
\hline 40 & $\begin{array}{l}\text { NBR Periodic Commission } \\
\text { Report of Retail Credits }\end{array}$ & 1 & 1 & 1 & 1 & 4 & 4 & M & 1.00 & PL/I & A & Y & $\mathrm{N}$ & 0 & 0 & 0 \\
\hline 41 & $\begin{array}{l}\text { NBR Extra Commission Report } \\
\text { of Retail Credits }\end{array}$ & 1 & 1 & 1 & 1 & 4 & 4 & M & 1.00 & $\mathrm{PL} / \mathrm{I}$ & A & Y & $\mathrm{N}$ & 0 & 0 & 0 \\
\hline 42 & $\begin{array}{l}\text { NBR Opening Commission } \\
\text { Report of Commercial Credits }\end{array}$ & 1 & 1 & 1 & 1 & 4 & 4 & M & 1.00 & PL/I & A & Y & $\mathrm{N}$ & 0 & 0 & 0 \\
\hline
\end{tabular}




\begin{tabular}{|c|c|c|c|c|c|c|c|c|c|c|c|c|c|c|c|c|}
\hline No & Identification & $\mathbf{E}$ & $\mathbf{R}$ & W & $\mathbf{X}$ & CFP & Effort & Type & Ratio & Tool & Quality & Batch & Online & Write & Exit & Module \\
\hline 43 & $\begin{array}{l}\text { NBR Periodic Commission } \\
\text { Report of Commercial Credits }\end{array}$ & 1 & 1 & 1 & 1 & 4 & 4 & M & 1.00 & $\mathrm{PL} / \mathrm{I}$ & A & Y & $\mathrm{N}$ & 0 & 0 & 0 \\
\hline 44 & $\begin{array}{l}\text { NBR Extra Commission Report } \\
\text { of Commercial Credits }\end{array}$ & 1 & 1 & 1 & 1 & 4 & 4 & M & 1.00 & $\mathrm{PL} / \mathrm{I}$ & A & Y & $\mathrm{N}$ & 0 & 0 & 0 \\
\hline 45 & $\begin{array}{l}\text { Facility to Relate Income Codes } \\
\text { with Product Codes }\end{array}$ & 1 & 1 & 1 & 1 & 4 & 4 & M & 1.00 & Cool:Gen & A & $\mathrm{N}$ & Y & 0 & 0 & 0 \\
\hline 46 & $\begin{array}{l}\text { List of Income Codes Related to } \\
\text { Product Codes }\end{array}$ & 1 & 1 & 1 & 1 & 4 & 8 & M & 2.0 & Cool:Gen & A & $\mathrm{N}$ & Y & 0 & 0 & 0 \\
\hline 47 & $\begin{array}{l}\text { Impair Flag Update for Risky } \\
\text { Credits }\end{array}$ & 1 & 5 & 2 & 1 & 9 & 16 & $\mathrm{~N}$ & 1.78 & $\mathrm{PL} / \mathrm{I}$ & A & Y & $\mathrm{N}$ & 1 & 0 & 1 \\
\hline 48 & $\begin{array}{l}\text { Calculating Effective Interest } \\
\text { Amount of Commercial Credits }\end{array}$ & 1 & 6 & 2 & 1 & 10 & 26 & $\mathrm{~N}$ & 2.60 & $\mathrm{PL} / \mathrm{I}$ & A & $\mathrm{Y}$ & $\mathrm{N}$ & 1 & 0 & 1 \\
\hline 49 & $\begin{array}{l}\text { Calculation Effective Interest } \\
\text { Rate(EIR) of Commercial } \\
\text { Credits }\end{array}$ & 1 & 2 & 2 & 1 & 6 & 12 & $\mathrm{~N}$ & 2.00 & $\mathrm{PL} / \mathrm{I}$ & A & Y & $\mathrm{N}$ & 1 & 0 & 1 \\
\hline 50 & $\begin{array}{l}\text { Calculating Adjustment Amount } \\
\text { of Commercial Credits }\end{array}$ & 1 & 2 & 2 & 1 & 6 & 13 & $\mathrm{~N}$ & 2.17 & $\mathrm{PL} / \mathrm{I}$ & A & Y & $\mathrm{N}$ & 1 & 0 & 1 \\
\hline 51 & $\begin{array}{l}\text { Customer Account Report } \\
\text { General Ledger Number Change }\end{array}$ & 1 & 1 & & 1 & 3 & 1 & M & 0.33 & $\mathrm{PL} / \mathrm{I}$ & A & Y & $\mathrm{N}$ & 0 & 0 & 0 \\
\hline 52 & $\begin{array}{c}\text { Recover Table Lock Escalation } \\
\text { Problem }\end{array}$ & 1 & 1 & 1 & 1 & 4 & 10 & M & 2.50 & $\mathrm{PL} / \mathrm{I}$ & A & Y & $\mathrm{N}$ & 0 & 0 & 0 \\
\hline 53 & Income Delivery Operations & 1 & 4 & 3 & 2 & 10 & 40 & $\mathrm{~N}$ & 4.00 & $\mathrm{PL} / \mathrm{I}$ & A & Y & $\mathrm{N}$ & 1 & 0 & 1 \\
\hline 54 & Pricing Service List & 1 & 1 & & 2 & 4 & 16 & M & 4.00 & Cool:Gen & A & $\mathrm{N}$ & Y & 0 & 0 & 0 \\
\hline 55 & Service Definition Operation & 1 & 2 & 1 & 3 & 7 & 16 & $\mathrm{~N}$ & 2.29 & Cool:Gen & A & $\mathrm{N}$ & $\mathrm{Y}$ & 0 & 1 & 0 \\
\hline 56 & Record Priority Screen & 1 & 1 & 1 & 1 & 4 & 8 & M & 2.00 & Cool:Gen & A & $\mathrm{N}$ & Y & 0 & 0 & 0 \\
\hline 57 & $\begin{array}{c}\text { Pricing Service code Product } \\
\text { Code Relation }\end{array}$ & 1 & 1 & 1 & 1 & 4 & 8 & M & 2.00 & Cool:Gen & A & $\mathrm{N}$ & Y & 0 & 0 & 0 \\
\hline 58 & Service Pricing & 3 & 1 & 3 & 1 & 8 & 24 & $\mathrm{~N}$ & 3.00 & Cool:Gen & A & $\mathrm{N}$ & Y & 1 & 0 & 0 \\
\hline 59 & $\begin{array}{l}\text { Business of Industry Price } \\
\text { Detail Entry }\end{array}$ & 2 & 3 & 1 & 2 & 8 & 22 & $\mathrm{~N}$ & 2.75 & Cool:Gen & A & $\mathrm{N}$ & Y & 0 & 0 & 0 \\
\hline 60 & Reference Price Detail Entry & 2 & 3 & 1 & 2 & 8 & 18 & $\mathrm{~N}$ & 2.25 & Cool:Gen & A & $\mathrm{N}$ & Y & 0 & 0 & 0 \\
\hline 61 & Special Price Detail Entry & 2 & 3 & 1 & 2 & 8 & 19 & $\mathrm{~N}$ & 2.38 & Cool:Gen & A & $\mathrm{N}$ & Y & 0 & 0 & 0 \\
\hline 62 & $\begin{array}{c}\text { Charge Commission Amount } \\
\text { Querying }\end{array}$ & 2 & 6 & & 4 & 12 & 38 & $\mathrm{~N}$ & 3.17 & Cool:Gen & A & $\mathrm{N}$ & Y & 0 & 1 & 1 \\
\hline 63 & $\begin{array}{l}\text { Calculation of Profitability of } \\
\text { Customer for Company }\end{array}$ & 1 & 2 & & 2 & 5 & 20 & M & 4.00 & $\mathrm{PL} / \mathrm{I}$ & A & Y & $\mathrm{N}$ & 0 & 0 & 1 \\
\hline 64 & Extract of Account Report & 1 & 3 & & 2 & 6 & 24 & $\mathrm{~N}$ & 4.00 & $\mathrm{PL} / \mathrm{I}$ & A & Y & $\mathrm{N}$ & 0 & 0 & 1 \\
\hline 65 & Revenue List & 1 & 3 & & 2 & 6 & 22 & $\mathrm{~N}$ & 3.67 & PL/I & A & Y & $\mathrm{N}$ & 0 & 0 & 1 \\
\hline 66 & $\begin{array}{l}\text { Campaign Parameter Entry } \\
\text { Screen Change }\end{array}$ & 1 & 1 & 1 & 2 & 5 & 8 & M & 1.60 & Cool:Gen & A & $\mathrm{N}$ & Y & 0 & 0 & 0 \\
\hline 67 & $\begin{array}{c}\text { Closing Accounts According to } \\
\text { Criteria }\end{array}$ & 1 & 4 & 1 & 2 & 8 & 24 & $\mathrm{~N}$ & 3.00 & $\mathrm{PL} / \mathrm{I}$ & A & Y & $\mathrm{N}$ & 0 & 0 & 1 \\
\hline 68 & General Ledger Number Update & 1 & 3 & 1 & 2 & 7 & 11 & $\mathrm{~N}$ & 1.57 & $\mathrm{PL} / \mathrm{I}$ & A & Y & $\mathrm{N}$ & 0 & 0 & 0 \\
\hline 69 & $\begin{array}{l}\text { Adding New Fields to the } \\
\text { Campaign Parameter Entry } \\
\text { Screen } \\
\text { Adding New Fields to the }\end{array}$ & 1 & 1 & 1 & 1 & 4 & 10 & M & 2.5 & $\mathrm{PL} / \mathrm{I}$ & A & Y & Y & 0 & 0 & 0 \\
\hline 70 & $\begin{array}{l}\text { Campaign Product Parameter } \\
\text { Entry Screen }\end{array}$ & 1 & & 1 & 1 & 3 & 8 & M & 2.67 & $\mathrm{PL} / \mathrm{I}$ & A & Y & Y & 0 & 0 & 0 \\
\hline 71 & $\begin{array}{l}\text { Customer Report Interest } \\
\text { Amount Setting }\end{array}$ & 1 & 2 & & 1 & 4 & 6 & M & 1.5 & PL/I & A & Y & $\mathrm{N}$ & 0 & 0 & 0 \\
\hline 72 & $\begin{array}{l}\text { Adding new Accounting Case } \\
\text { To the Income Return Process }\end{array}$ & 1 & 2 & 1 & 1 & 5 & 10 & M & 2 & Cool:Gen & A & $\mathrm{N}$ & Y & 0 & 0 & 1 \\
\hline 73 & $\begin{array}{l}\text { Retail Credits Interest Discount } \\
\text { Control Link }\end{array}$ & 1 & 1 & & 1 & 3 & 8 & M & 2.67 & Cool:Gen & A & $\mathrm{N}$ & $\mathrm{Y}$ & 0 & 0 & 0 \\
\hline 74 & Customer Transfer Check Link & 1 & 1 & & 1 & 3 & 8 & M & 2.67 & Cool:Gen & A & $\mathrm{N}$ & Y & 0 & 0 & 0 \\
\hline 75 & $\begin{array}{c}\text { Cost Matrix Special Price } \\
\text { Definition Log List }\end{array}$ & 1 & 1 & & 2 & 4 & 6 & $\mathrm{M}$ & 1.5 & $\mathrm{PL} / \mathrm{I}$ & A & Y & $\mathrm{N}$ & 0 & 0 & 0 \\
\hline
\end{tabular}




\begin{tabular}{|c|c|c|c|c|c|c|c|c|c|c|c|c|c|c|c|c|}
\hline No & Identification & $\mathbf{E}$ & $\mathbf{R}$ & $\mathbf{W}$ & $\mathbf{X}$ & CFP & Effort & Type & Ratio & Tool & Quality & Batch & Online & Write & Exit & Module \\
\hline 76 & $\begin{array}{c}\text { Accounting Transaction Group } \\
\text { List Service }\end{array}$ & 1 & 1 & & 1 & 3 & 8 & M & 2.67 & Cool:Gen & A & $\mathrm{N}$ & Y & 0 & 0 & 0 \\
\hline 77 & Account Plan Service & 1 & 1 & & 1 & 3 & 8 & M & 2.67 & Cool:Gen & $\mathrm{A}$ & $\mathrm{N}$ & Y & 0 & 0 & 0 \\
\hline 78 & $\begin{array}{l}\text { Accounting Transaction List } \\
\text { Performance Enhancement }\end{array}$ & 1 & 1 & & 1 & 3 & 7 & M & 2.33 & Cool:Gen & A & $\mathrm{N}$ & Y & 0 & 0 & 0 \\
\hline 79 & $\begin{array}{c}\text { Simulation facility to calculate } \\
\text { EIR, adjustment and effective } \\
\text { amount }\end{array}$ & 1 & 1 & & 2 & 4 & 8 & & 2 & Cool:Gen & A & $\mathrm{N}$ & Y & 0 & 0 & 0 \\
\hline 80 & Valuable Fund Tax Transfer & 1 & 3 & 1 & 1 & 6 & 10 & & 1.67 & $\mathrm{PL} / \mathrm{I}$ & $\mathrm{A}$ & $\mathrm{Y}$ & $\mathrm{N}$ & 0 & 0 & 1 \\
\hline 81 & $\begin{array}{l}\text { General Ledger Number } \\
\text { Update for Unit }\end{array}$ & 1 & 2 & & 1 & 4 & 4 & & 1 & $\mathrm{PL} / \mathrm{I}$ & A & Y & $\mathrm{N}$ & 0 & 0 & 0 \\
\hline 82 & Credit Read Service & 1 & 1 & & 1 & 3 & 8 & & 2.67 & Cool:Gen & A & $\mathrm{N}$ & Y & 0 & 0 & 0 \\
\hline 83 & $\begin{array}{l}\text { Retail Credits Master } \\
\text { Information Read Service }\end{array}$ & 1 & 1 & & 1 & 3 & 8 & & 2.67 & Cool:Gen & A & $\mathrm{N}$ & Y & 0 & 0 & 0 \\
\hline 84 & $\begin{array}{c}\text { Parametric Accounting Detail } \\
\text { Read Service }\end{array}$ & 1 & 2 & & 2 & 5 & 10 & & 2 & Cool:Gen & $\mathrm{A}$ & $\mathrm{N}$ & Y & 0 & 0 & 0 \\
\hline 85 & $\begin{array}{c}\text { Rediscount Information Update } \\
\text { Service }\end{array}$ & 1 & 1 & 1 & 1 & 4 & 8 & & 2 & Cool:Gen & A & $\mathrm{N}$ & $\mathrm{Y}$ & 0 & 0 & 0 \\
\hline 86 & $\begin{array}{c}\text { Amortization Information } \\
\text { Update Service }\end{array}$ & 1 & 1 & 1 & 1 & 4 & 8 & & 2 & Cool:Gen & A & $\mathrm{N}$ & Y & 0 & 0 & 0 \\
\hline 87 & $\begin{array}{l}\text { Commission Report new fields } \\
\text { request for Retail Credits }\end{array}$ & 1 & 1 & & 2 & 4 & 3 & & 0.75 & $\mathrm{PL} / \mathrm{I}$ & A & $\mathrm{Y}$ & $\mathrm{N}$ & 0 & 0 & 0 \\
\hline 88 & $\begin{array}{l}\text { Commission Report new fields } \\
\text { request for Commercial Credits }\end{array}$ & 1 & 2 & & 2 & 5 & 5 & & 1 & $\mathrm{PL} / \mathrm{I}$ & A & $\mathrm{Y}$ & $\mathrm{N}$ & 0 & 0 & 0 \\
\hline
\end{tabular}

\section{Appendix B. Small Enhancements Documentation (2 Examples)}

\section{1) Changing General Ledger Numbers of Retail Credits}

There is a ledger number for each product code. If the product code is changed, ledger number must be changed.

Trigger: Product code change

Entry: Product Code

Read: General Ledger (1 Read)

Write: General Ledger (1Write)

Error Message: 1 Exit (General Ledger number is not defined related to product code)

$1(\mathrm{E})+1(\mathrm{R})+1(\mathrm{~W})+1(\mathrm{X})=4 \mathrm{CFP}$

Quality: A

Effort Enh. $=4$ hours

Data Group: General Ledger

\section{2) Changing General Ledger Numbers of Commercial Credits}

There is a ledger number for each product code. If the product code is changed, ledger number must be changed.

Trigger: Product code change

Entry: Product Code

Read: General Ledger (1 Read)

Write: General Ledger (1Write)

Error Message: 1 Exit (General Ledger number is not defined related to product code)

$1(\mathrm{E})+1(\mathrm{R})+1(\mathrm{~W})+1(\mathrm{X})=4 \mathrm{CFP}$

Quality: A

Effort Enh. $=4$ hours

Data Group: General Ledger 